\title{
Role of Computerized AIS Applications in Preserving Organizational Financial Performance during COVID19: Moderating Role of Accountants' Experience
}

\author{
Firas Hashem ${ }^{1}$ \\ ${ }^{1}$ Accounting Department, Tafila Technical University, Jordan \\ Correspondence: Firas Hashem, Accounting Department, Tafila Technical University, Jordan.
}

Received: February 7, 2021

Accepted: March 19, 2021

Online Published: March 29, 2021

doi:10.5539/ibr.v14n4p87

URL: https://doi.org/10.5539/ibr.v14n4p87

\begin{abstract}
Current study aimed at examining the role of AIS application in preserving financial performance of organizations during COVID19 pandemic. Depending on quantitative approach, study utilized a questionnaire built on likert scale which was distributed on (109) individuals within Jordanian organizations. Results of study indicated that accounting information systems contributed to the continuous follow-up and knowledge of the financial performance of the organizations during the pandemic period, which in turn supported the principle of correct and quick decision-making that is in the interest of shareholders, working individuals and customers by taking precautionary measures to ensure that the organization does not reach financial insolvency in view of financial data that together constitute the informational outputs of accounting information systems. This support was backed up with the moderating variable of accountants' experience, experience in this case managed to help accountants predict the coming situations and help the organization overcome the obstacles based on their previous experiences in similar situations. Study recommended the necessity of activating risk management strategies by organizations when facing crises and epidemics
\end{abstract}

Keywords: accounting information systems, distant work, COVID19, accountant, experience, disclosure, financial performance, lockdown, trading, closure, quarantine

\section{Introduction}

The Internet represented all the services and tools it provides, the ideal solution for communication and completion of work during the period of the Corona pandemic that stormed the world during the last quarter of the year 2019 and until this day from the year 2021 (He and Harris, 2020). The world's attention has turned to technology in all its forms and its dependence on the Internet to facilitate business and prevent the global economy from being affected by this pandemic and the resulting closures of many organizations as a way to prevent the spread of the virus further and reduce the number of infections and deaths to a minimum (Basu et al, 2020).

Many sectors have adopted the Internet and technology in all its forms, so that education has moved from real-life education to distance education as a result of the closure of schools, universities, and training and educational institutes (Talwar et al, 2021). The world's governments were also forced to control gatherings and move from one place to another, which led to many organizations relying on remote work in their work, including the manufacturing, production, services, administration and management sectors of all kinds.

The idea of the spread of an epidemic classified by the World Health Organization as an epidemic posed a kind of challenge that the world had never experienced before except in cases of wars and political upheavals, which are now under control through peace treaties and the cessation of war (Oldekop et al, 2021). As for the spread of an epidemic as a pandemic, it was so dangerous that governments were forced to close many of their sectors in the hope of controlling the spread and as an attempt to support the health sector in it to reduce the number of infections and thus avoid pressure on health sector institutions (Folger-Laronde et al, 2020).

Estimates received from the International Monetary Fund indicated an increase in the rate of change in global debt (relative to gross domestic product) due to the Corona pandemic, by $18.7 \%$ compared to a rate of change of $10.5 \%$ due to those repercussions resulting from the global financial crisis in 2008, in addition to an expected negative increase in the rate of change of the government fiscal deficit in the world (relative to GDP) by $10 \%$ 
due to the Corona pandemic, compared to a rate of change of $4.9 \%$ during the period of the global financial crisis in 2008 (Colenda et al, 2020).

\subsection{Introduce the Problem}

Organizations found themselves in a position that requires them to stand in a completely different position from their nature and try to complete their work and conduct their operations remotely by relying on the Internet with its tools and capabilities (Parr et al, 2020). Among the internal processes affected by the Corona pandemic are accounting operations in all its forms due to the imposition of quarantine and the prevention of individuals from gathering and meeting as a means to mitigate the spread of the pandemic, and therefore organizations have been running their accounting matters through the Internet with all its tools and capabilities in order to ensure proceeding their operations in an accurate and capable manner, in addition to that, organizations found it important to find another route in order to guarantee accounting operations that have the ability to contribute to transparency and disclosure of the organization even during the pandemic period (World Bank, 2020).

According to a report by Deloitte (2020), organizations indicated that although the pandemic is global, its impact on the financial performance of organizations was of moderate severity during the first quarter of 2020, because the epidemic spread globally and significantly in mid-March 2020, and from here, the reality of organizations has moved from medium risk to severe risk as a result of the total closures that governments have applied to all sectors in order to limit the pandemic and prevent its spread further.

The importance of suh problem lies in the fact that many sectors had been greatly affected, starting from mid-March 2020, and it included consumer goods, entertainment and travel sectors, industries and mining, which would have affected oil prices, which fell significantly.

As for Ozili (2020) and Razumovskaia et al (2020), it was indicated that COVID19 impact on financial performance of organizations appeared through the negative impact on revenues and profitability, and thus the effect on the financial position of the organization due to the global economic downturn accompanying the pandemic, which was accompanied by a high level of uncertainty related to profitability and the value of assets and stocks. In addition, the pandemic and the closures that came with it led to an increase in credit risks, high unemployment rates and the economic downturn mentioned previously (Kalbouneh et al, 2011).

This study touches a sensitive area in which a very important part of the organization (accounting) had to rely on computerized and virtual working sphere, this idea increased risks of fraud, piracy and errors in entries which can lead to malfunctioned outputs that cannot be relied on. Organizations in general have chosen to depend computerized AIS as an approach to ensure the conduct of their accounting business remotely, and all accounting applications have been adopted in order to ensure high quality, accurate and reliable accounting information and reports explaining a picture of the actual and real situation of the organizations (Hamdan, 2014).

Based on above argument; current study aimed at examining the role of computerized AIS applications on preserving financial performance of organizations during COVID19 pandemic through the moderating role of accountants' experience. Current study hypothesize that computerized AIS applications managed to preserve a good level of financial performance among organizations due to its ability to meet the health precautions which were developed by WHO including the dangers of gatherings, meetings, and the need to apply a full quarantine on the country including all operating entities in it.

\subsection{Importance of the Problem}

A spread pandemic is something new in the current era, before, the world witnessed the spread of HIV, then appeared SARS pandemic, but none of them were uncontrollable as much as COVID19, as it can be seen the pandemic started in China through the last quarter of 2019, and it continued till 2021, So far, there appeared to valid approach to control its spread, and its influence continues to negatively touch all aspects of life.

The current study came as a sensitive point in which researcher aimed to shed the light on what accounting profession has faced through this pandemic, and how the financial performance of organizations was impacted in terms of governance, disclosure, revenues, and overall existence. Also, the importance of current study lies in its ability to confirm that with specific measures taken into consideration, the idea of managing financial performance of organizations remotely can actually be done through building higher awareness in AIS applications, increase the level of their security and shed the light on their orientation in managing finances.

\subsection{Relevant Scholarship}

Accounting Information Systems (AIS)

The idea of AIS is based on the existence of an electronic system for collecting, processing and retaining 
financial and accounting data in order to support and guide decision makers in the organization (Al Hanini, 2015). In this case, computers are the main focus of accounting information as they form a platform for operating accounting information systems and synthesizing them in a way that is capable of presenting them when needed accurately, quickly and safely for decision-making (Amahalu et al, 2015; Considine et al, 2012).

Arcega et al (2015) indicated that AIS are a group of systems that contain many steps, actions, components and resources, which together constitute the unit responsible for managing, processing and controlling accounting data in order to produce information that contributes to supporting decision-makers (Murungi and Kayigamba, 2015). As for Nyang'au et al (2015), it was confirmed that AIS, in their current state, are able to perform their function by relying on many components (human, graphical and infrastructure) that work together in order to create a correct framework that ensures achieving goals and taking the necessary decisions when needed.

Ware (2015) indicates that AIS collects, processes, analyzes and converts data into output by relying on specially designed computers for this purpose in order to reach outputs and convert them into usable information. As for Khan (2017) emphasized that AIS with all its equipment ensure the policies and procedures that supports the conversion of accounting inputs into understandable outputs that give a true impression on the organization in order to support its activities and provide shareholders, owners, working individuals, clients and stakeholders within the organization's environment effectively, quickly, accurately and in a timely manner.

\section{Components of AIS}

Moroșan-Dănilă et al (2015) indicated that in a typical organizational environment, accounting information systems consist of many components, the most important of which are those in figure 2 below:

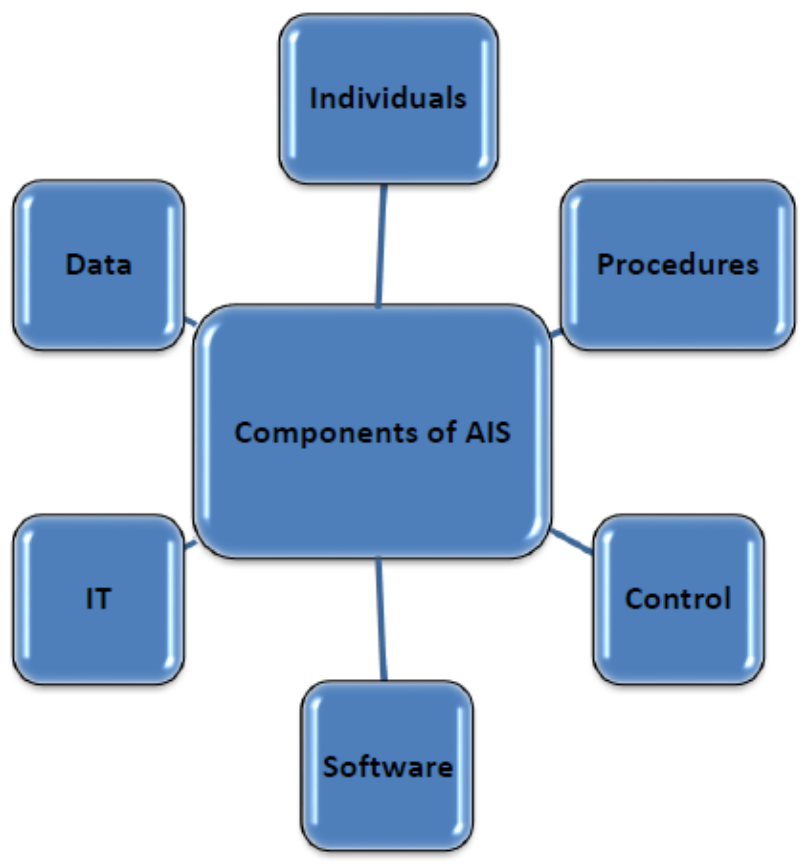

Figure 1. Components of AIS (Ganyam and Ivungu, 2019)

As shown in the above figure, the components of AIS are based on many components, in which each component is important in reaching the required outputs and with specifications capable of achieving the required (Prasad and Green, 2015). Budiarto et al (2018) indicates that individuals played an important role during the Corona pandemic in achieving the required accounting information systems, as they are the vital component of the system and they are the ones who control the system's functions and inputs by paying attention to the primary data entry mechanism, its validity and accuracy, and Avoid messing with it. As for Haleem et al (2019), it was confirmed that individuals contribute significantly to the quality of the information that the systems produce through internal control, technology and infrastructure requirements, in addition to the daily use of accounting information systems.

Financial Performance

The concept of performance has received the attention and from academics and researchers interested in the field of management and financial management, as performance is the first motivation to maintain the existence of 
organizations and it is the only way that contributes significantly to extending the life of the organization and developing its competitive advantage (Aifuwa et al, 2020). The concept of performance as a word refers to the correct completion of the tasks or tasks required in a correct manner that is characterized by comprehensiveness and continuity, that is, performance from an administrative point of view indicates the ability of the organization to achieve all its goals, specifically long-term goals, and therefore many organizations seek to enhance their performance in the optimal way (Widiatmika and Darma, 2018).

According to Al-Hattami et al (2021) performance is one of the most important marketing factors for the organization, so the idea of paying attention to organizational performance will positively affect the organization, specifically AIS. Thus, the success of employing AIS applications in organizations has a positive impact on performance measures such as profits, return on investment and cash flow. The reason for the high performance measures is due to the success of the AIS application in the organization due to the ability to provide high-quality information that depends on the quality of the system, in addition to the satisfaction of the user (employees).

Regarding financial performance, Yan and Sloan (2016), Galant and Cadez (2017) and Post and Byron (2015) have indicated that the financial performance is the extent to which the organization can achieve a margin of safety through developing its ability to address financial risks and challenges, which would avoid financial insolvency. That is, financial performance is the organization's ability to create a kind of financial balance by providing liquidity to meet its financial obligations in addition to achieving a good profit margin based on low costs (Ganyam and Ivungu, 2019; Pirayesh et al, 2018).

Financial performance is one of the indicators used to measure the success of organizations in terms of financial returns. It is often used by investors as a benchmark for performing due diligence and assessing investment status; it is also used as a tool by government monitors to assess compliance with regulatory measures and monitor the overall safety of the financial sector (Friede et al, 2015). As for Budiarto et al (2018), it was confirmed that performance is one of the criteria for judging the extent to which the organization achieves its objectives, survival and continuity in the market despite the existence of competition and is able to achieve balance between its shareholders and the individuals working in it.

Thus, the performance can be indicated through the equation below:

\section{Total Performance of an Organization = Profit - Cost}

According to Beg (2018), the financial performance represents the financial health of the organization and its ability to fulfill its financial obligations towards its projects and individuals working in it in addition to the possibility of commitment to provide market services in the future, so the financial performance is nothing but the degree to which the organization achieves its long-term financial goals from During the measurement of the adopted policies and examining the results obtained in financial terms.

Financial performance, as indicated by both Ali et al (2016) and Esmeray (2016), is viewed by measuring the degree to which the organization achieves its objectives with reference to investment returns, which are measured from the perspective of investors and accounting returns, which are measured by how the organization responds to its plans and the level of its profits after deduction of operational and production costs. Ozili (2020) emphasized that the main purpose of measuring financial performance is to provide data and information to shareholders and stakeholders in order to make sound and thoughtful organizational decisions, in addition to measuring market share and the competitive advantage of the organization.

AIS and Financial Performance during the Pandemic

According to Daoud and Triki (2013), AIS is one of the most important pillars on which ERP is based, and whenever AIS is advanced, the ERP is more efficient and higher performance because AIS has great potentials that will advance the performance of organizations and their development through a positive impact on employee performance, and from the effective performance of the employees, there will inevitably be a positive impact on the performance of the organization as a whole. Urquia Grande et al and Soudani (2012) supported the same idea arguing that the importance of AIS and its impact on the organizational performance is concentrated in the ability of AIS with its components to work together in order to collect and process data and produce results of high quality and conform to reality and thus help and support decision-makers in making the right decision at the right time. AIS have a direct impact on many elements of organizational performance such as performance management and financial performance management.

On the same track, Grande (2011) argued there is a close relationship between organizational performance and AIS, as there is a close relationship that contains the positive impact of AIS on the organization's performance by managing financial and banking matters in a systematic manner that gives a clear picture of the organization's 
financial condition, existing gaps, and places in which it is possible to Development is carried out in order to reach a state of organizational performance development.

According to Nazar (2020) the negative impact of the Corona pandemic on the economic sectors at the local and global level has led many organizations to take many measures and precautionary measures to face the repercussions resulting from the interruption of the work of various economic activities, by reducing interest rates and reducing the compulsory reserve ratio to increase the ability of commercial organizations to continue, in addition to providing facilities to customers and companies by postponing loan installments for a specific period of time, with the aim of continuing the wheel of the economy. On the other hand, Ozili (2020) argued that in spite of all the measures taken globally to mitigate the repercussions of the Corona virus on local economies, the IMF forecasts indicate that the world will enter an economic crisis that exceeds the intensity of the global financial crisis in 2008, and the reason for this is due to the sharp contraction in Economic activity in all sectors and a decline in public financial revenues. It is also expected that the deficit in all government budgets will increase, which will lead to an increase in the need for borrowing in order to stimulate economies in the coming years.

Folger-Laronde et al (2020) and Khullar et al (2020) believes that accounting information systems had a great role in giving a clear picture of the nature of the differences and influences that affected the financial performance of organizations during the pandemic period by referring to the situation in which governments were forced to impose complete closures, which led to the blocking of suppliers and exporters from organizations Consequently, either the stock is corrupted or its expiration date, in addition to the cases in which there was no type of commercial activity by consumers as a result of the quarantine except for the necessary supplies such as food, drink and medical supplies. As for Erdem (2020), Yarovaya et al (2021) it was made clear that it is correct to have a positive effect for the applications of accounting information systems during the pandemic period in giving Readings about the financial situation of the organization, but the experience of accountants contributed greatly to providing organizations with individuals who were able to deal with these situations - judging by their experience - and thus give a future picture of the mechanism of developing the financial position of the organization after the end of the pandemic and in a way in which individuals with Experience in situations they were previously exposed to and accounting matters that would solve the crisis, and this was also agreed upon by Rababah et al (2020) in addition to Ichsan et al (2021).

\subsection{State Hypotheses and Their Correspondence to Research Design}

Launching from previous studies presented in the literature review, researcher was able to build following model in order to explain the relationship between variables (dependent and independent):

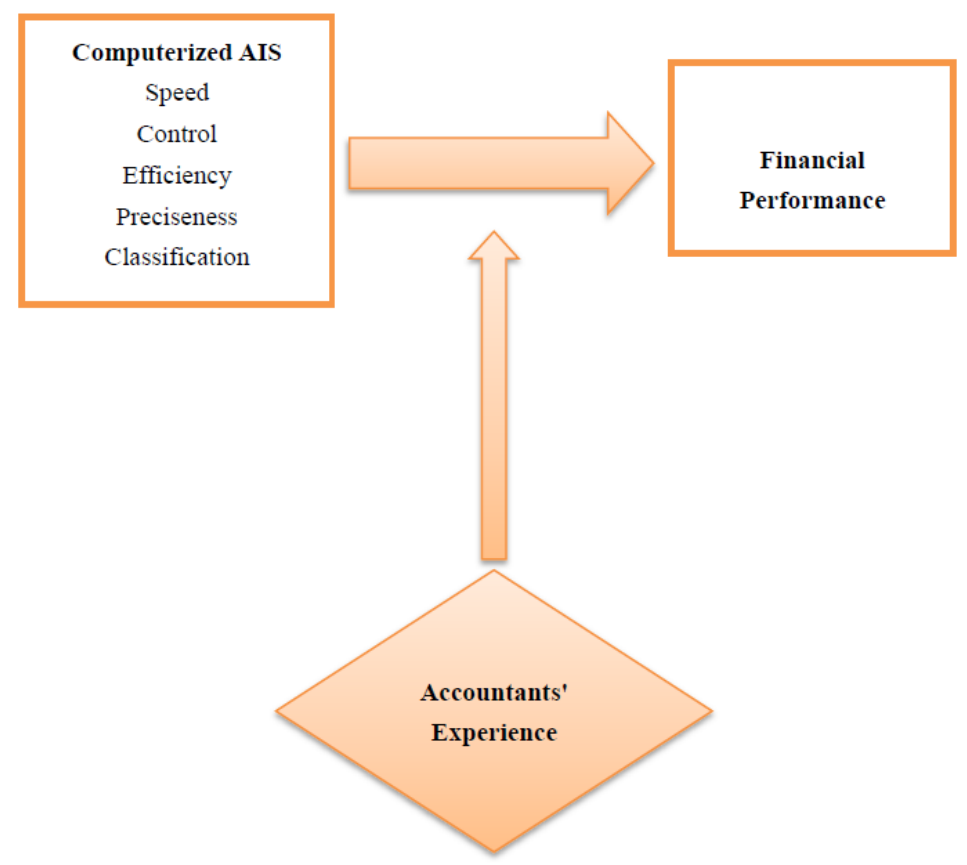

Figure 2. Study Model (Agung, 2015) 
Literature review and many scholarly studies indicated that many organizations have depended on e-solutions as a respond to COVID19. This appeared through many initiatives which took place by decision makers to work remotely and manage organizational affairs through internet applications like meetings, financial reports and managing personnel. However, considering that researcher of current study hypothesized a positive influence of computerized AIS application on financial performance, following hypotheses were developed:

Main Hypothesis:

Computerized AIS applications positively influence financial performance of organizations during COVID19 Sub-Hypotheses:

H1: Speed in computerized AIS applications positively influenced financial performance of organizations during COVID19

H2: Control in computerized AIS applications positively influenced financial performance of organizations during COVID19

H3: Efficiency in computerized AIS applications positively influenced financial performance of organizations during COVID19

H4: Preciseness in computerized AIS applications positively influenced financial performance of organizations during COVID19

H5: Classification in computerized AIS applications positively influenced financial performance of organizations during COVID19.

\section{Method}

\subsection{Methodological Approach}

Current study aimed at realizing main aim depending on numerical data. The numerical data were collected through quantitative approach utilizing a questionnaire. The questionnaire was built on liker scale (5 strongly agree, 4 agree, 3 neutral, 2 disagree, and 1 strongly disagree). The questionnaire consisted of two main sections, the first took into perspective demographics of respondents (age, gender, education and experience), while the other section consisted of statements related to study variables which included (speed, control, preciseness, efficiency, and classification) as sub-variables of the independent variable and financial performance as a dependent variables. The questionnaire consisted of (34) statements in its final version after reviewing it by a group of specialized professors in the field of accounting information systems.

\subsection{Participant (Subject) Characteristics}

Population of study consisted of all financial managers of Jordanian organizations. A sample of (150) individuals were chosen to represent population of study as a convenient sample to take part in the questionnaire. After application process, researcher was able to retrieve (109) properly filled questionnaires which indicated a response rate of $(72.6 \%)$ as statistically accepted.

\subsection{Sampling Procedures}

Sampling procedures took pace through contacting HR department of each organization which was chosen randomly based on the fact that those organizations were still operating during the pandemic. The main aim and objectives of study were described, and the HR department gained the approval from the higher management in order to proceed with the process of application.

The questionnaire was uploaded online and sent via email to all participating individuals of the sample, they were first introduced to the aim and objectives of study, then they were exposed to a consent form that clarifies their rights to withdraw from study and face no pressure in taking part in filling the questionnaire.

\subsubsection{Data Screening and Analysis}

SPSS was employed in order to screen and analyze gathered data, Cronbach alpha was employed in order to test tool reliability to be used in study, test results that Alpha value $=0.967$ was acceptable since it was greater than the cutoff value 0.60 .

\section{Results}

\subsection{Statistics and Data Analysis}

Below table showed results of respondents' demographics as according to their (gender, age, experience and qualification). As it appeared from the table, majority of respondents seemed to be (Males) with a percentage of 
(77.1\%) compared to females who formed $(22.9 \%)$ of total sample. On the other hand, majority of respondents were within age range of (39-45) years old forming (33.9\%) of total sample, and their qualification was mainly (BA) forming (50\%) of the sample, experience of majority of individuals who responded to the questionnaire was more than (15) forming (41.3\%) of the sample.

Table 1. Sample Statistics

\begin{tabular}{cccc}
\hline & & Gender & \% \\
\hline & & $f$ & 77.1 \\
Valid & Male & 84 & 22.9 \\
& Female & 25 & 5.5 \\
& & Age & 28.4 \\
\hline Valid & $25-31$ & 6 & 33.9 \\
& $32-38$ & 31 & 32.1 \\
\hline & $39-45$ & 37 & 55.0 \\
& +46 & 35 & 34.9 \\
\hline Valid & & 60 & 10.1 \\
\hline & BA & 38 & 4.6 \\
\hline MA & Educational Level & 17.4 \\
\hline & PhD & 11 & 36.7 \\
\hline
\end{tabular}

\section{Questionnaire Analysis}

Table below showed attitudes of respondents regarding statements of questionnaire. Results indicated that individuals who took part in the questionnaire seemed to have high level of awareness regarding presented variables which appeared based on their positive attitudes below; the table indicated that all statements of questionnaire scored higher than mean of scale 3.00 which resembled a high level of awareness and a good attitude from respondents. Also, table showed that the highest statement in terms of means appeared to be (control) stemming from the variable of AIS articulated "Computerized AIS achieves a quality level by focusing on all of the planning, implementation, review and auditing elements " and scoring a mean of (4.32/5.00), on the other hand, the least positively answered statement stemmed from the variable of (preciseness) which was articulated "Computerized AIS provided the managers with the necessary information and by that assisting them in decision-making during the quarantine" and scoring a mean of (3.90/5.00).

Table 2. Questionnaire Statistics

\begin{tabular}{|c|c|c|}
\hline Statement & Mean & Std. Deviation \\
\hline \multicolumn{3}{|l|}{ Computerized AIS } \\
\hline \multicolumn{3}{|l|}{ Speed } \\
\hline 1. There is a breakneck speed in the processing and execution of financial data & 3.87 & 1.019 \\
\hline $\begin{array}{l}\text { 2. Computerized AIS helps the administration by providing it with the necessary and } \\
\text { timely data. }\end{array}$ & 3.98 & 1.018 \\
\hline $\begin{array}{l}\text { 3. Computerized AIS has been a means to facilitate cooperation and understanding } \\
\text { between components and elements of management information systems }\end{array}$ & 3.75 & 1.038 \\
\hline $\begin{array}{l}\text { 4. Computerized AIS contributed to monitoring and recording accounting business and } \\
\text { preparing reports and transactions in official records during the pandemic period }\end{array}$ & 4.06 & .993 \\
\hline $\begin{array}{l}\text { 5. Computerized AIS has contributed to the processing of financial and accounting data } \\
\text { and its processing for the decision maker and maker }\end{array}$ & 3.86 & 1.014 \\
\hline $\begin{array}{l}\text { 6. AIS has adopted computerized accrual in its way of operating, where expenditures must } \\
\text { match returns }\end{array}$ & 4.26 & .775 \\
\hline \multicolumn{3}{|l|}{ Control } \\
\hline 7. There is monitoring and evaluation of economic activities in the facility & 4.03 & .957 \\
\hline $\begin{array}{l}\text { 8. Computerized AIS helped the administration carry out the business during the } \\
\text { pandemic period }\end{array}$ & 4.19 & .726 \\
\hline $\begin{array}{l}\text { 9. Computerized AIS provided services in carrying out various types of administrative } \\
\text { tasks during the pandemic period }\end{array}$ & 4.17 & .918 \\
\hline $\begin{array}{l}\text { 10. Computerized AIS has provided a lot of help during the pandemic by leveraging } \\
\text { quantitative and objective metrics to achieve accounting business goals. }\end{array}$ & 4.05 & .750 \\
\hline
\end{tabular}


11. Computerized AIS achieves a quality level by focusing on all of the planning, implementation, review and auditing elements

\section{Efficiency}

12. Computerized accounting information systems ensure that the management is supplied $4.31 \quad 703$ with the necessary information when it is needed

13. Computerized AIS helps the management in making appropriate decisions from amon the range of alternatives available

14. Computerized AIS is characterized by flexibility and scalability

15. These systems are characterized by their ability to keep pace with the needs an developments that arise up-to-date through their development

16. Computerized AIS is characterized by dynamism and constant movement in achieving the desired goals

\section{Preciseness}

17. Computerized AIS relies on the accounting equation (total assets = total liabilities + equity)

18. Computerized AIS contributes to processing data and providing information that is accurate and extremely fast

19. Computerized AIS has proven to be the important method in monitoring a facility's financial activity during the pandemic

20. Computerized AIS contributed to reducing the possibility of error by making it easier to use accounting information by working on a computer

21. Computerized AIS provided the managers with the necessary information and by that assisting them in decision-making during the quarantine

22. Computerized AIS keeps accounting activities up-to-date in an automated way during the pandemic

\section{Classification}

23. Computerized AIS automates accounting information to make it ready for use across the organization during the pandemic period

24. Computerized AIS was the medium and tool of communication between administrative levels during the pandemic period

25. Computerized AIS components express financial transactions and the way they a grouped and classified into major and sub-groups

26. Computerized AIS provided protection for property assets in the facility during the pandemic

27. Computerized AIS provided the financial reports that organizations needed in time to make a decision in the face of the pandemic

28. Computerized AIS revealed the facility's financial position during the pandemic

\section{Financial Performance}

29. The pandemic urged organizations to depend on e-tools for financial management

30. Depending on electronic means was the only solution during the pandemic

31. Computerized accounting systems helped to close the gap during the lockdown

32. Organizations depended on distance work during the pandemic which was applied on financial practices

33. Many organizations' financial performance was negatively influenced by the pandemic

34. The government accredited reported outcomes from computerized accounting information systems

\section{Descriptive Statistics}

Total means of variables were taken as according to total statements' means. It appeared that the highest variables in terms of mean was (Efficiency) scoring a mean of (4.19/5.00) and indicating a positive attitudes from respondents regarding the variables utilized in the study. Results indicated that respondents saw in AIS applications during the pandemic as an approach to build up more efficient results giving the circumstances of lockdown and the inability to do an actual financial work in reality, not to mention the total lockdown which stopped all kinds of profit (trade activities) reaching a state of some organizations recording $\$ 0$ income after recording millions of dollars each day. So, AIS applications online and based on experience of individuals were able to retrieve valid and realistic data for the financial performance of the organization during the period of the total and partial lockdown. 
Table 3. Variables Statistics

\begin{tabular}{lll}
\hline & Mean & Std. Deviation \\
\hline Computerized AIS & & .79059 \\
Speed & 3.9648 & .65724 \\
Control & 4.1505 & .63127 \\
Efficiency & 4.1963 & .69503 \\
Preciseness & 4.0352 & .63951 \\
Classification & 4.0550 & .67124 \\
Financial Performance & 4.1269 & \\
\hline
\end{tabular}

\section{Hypotheses Testing}

Multiple regression and linear regression were used in order to test hypotheses and indicate their acceptance and their variance. Following part presented testing of each hypothesis generated from problem statement:

\section{First Hypothesis:}

Computerized AIS applications affect financial performance of organizations during COVID19

Table 4. Testing First Hypothesis

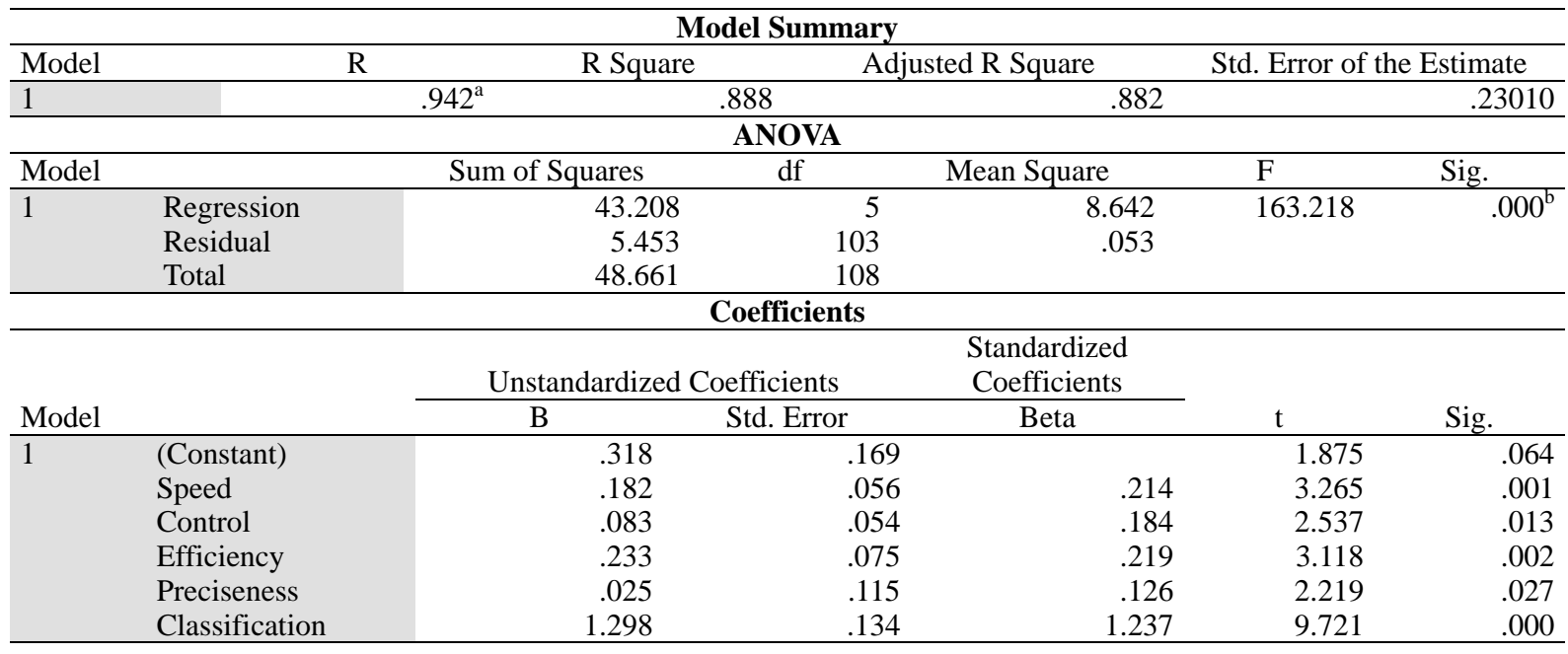

Multiple regression was used to test above hypothesis, $r=0.942$ reflected high and positive relationship between the independent variables and the dependent variable. Also, it was found that the independent variables explained $88.8 \%$ in the variance of the dependent variable. Also it was found that $\mathrm{F}$ value was significant at 0.05 level, that meant the hypothesis was accepted and "Computerized AIS applications affect financial performance of organizations during COVID19". Following table summarized the results of correlation test between the independent variables and the dependent variable, it was found that the highest relationship was between classification and financial performance since $r=0.931$.

Table 5. Correlation

\begin{tabular}{llc}
\hline & & Performance \\
\hline Speed & Pearson Correlation & $.711^{* * *}$ \\
& Sig. (2-tailed) & .000 \\
Control & N & 109 \\
& Pearson Correlation & $.661^{* *}$ \\
Efficiency & Sig. (2-tailed) & .000 \\
& $\mathrm{~N}$ & 109 \\
& Pearson Correlation & $.655^{* *}$ \\
Preciseness & Sig. (2-tailed) & .000 \\
& $\mathrm{~N}$ & 109 \\
& Pearson Correlation & $.847^{* *}$ \\
& Sig. (2-tailed) & .000 \\
\hline
\end{tabular}




\begin{tabular}{llc}
\hline Classification & Pearson Correlation & $.931^{* *}$ \\
& Sig. (2-tailed) & .000 \\
& $\mathrm{~N}$ & 109 \\
\hline
\end{tabular}

\section{Second Hypotheses:}

There is a significant difference in the effect of Computerized AIS applications on financial performance of organizations during COVID19 due to accountants' experience.

Table 4. Testing First Hypothesis

\begin{tabular}{|c|c|c|c|c|c|}
\hline \multicolumn{6}{|c|}{ Tests of Between-Subjects Effects } \\
\hline Dependent Variable: & Performance & & & & \\
\hline Source & $\begin{array}{l}\text { Type III } \\
\text { Squares }\end{array}$ & df & Mean Square & $\mathrm{F}$ & Sig. \\
\hline Corrected Model & $48.629^{\mathrm{a}}$ & 45 & 1.081 & 2100.758 & .000 \\
\hline Intercept & 833.316 & 1 & 833.316 & 1619966.477 & .000 \\
\hline AIS & 35.570 & 32 & 1.112 & 2160.847 & .000 \\
\hline experience & .430 & 3 & .143 & 278.711 & .000 \\
\hline AIS * experience & 1.045 & 10 & .105 & 203.212 & .000 \\
\hline Error & .032 & 63 & .001 & & \\
\hline Total & 1905.083 & 109 & & & \\
\hline Corrected Total & 48.661 & 108 & & & \\
\hline
\end{tabular}

2 way ANOVA was used to test $2^{\text {nd }}$ hypothesis, it was seen that $\mathrm{F}$ value $=203.212$ was significant at 0.05 level that meant there was a significant difference in the effect of Computerized AIS applications on financial performance of organizations during COVID19 due to accountants' experience.

By using scheffe test, it was found that the effect Computerized AIS applications on financial performance of organizations during COVID19 increased in the high experienced accountants as shown in the following table:

Table 5. Scheffe Test

\begin{tabular}{|c|c|c|c|c|c|c|}
\hline \multicolumn{7}{|c|}{ Multiple Comparisons } \\
\hline \multicolumn{7}{|c|}{ Dependent Variable: $\quad$ Performance } \\
\hline \multicolumn{7}{|c|}{ Scheffe } \\
\hline \multirow[b]{2}{*}{ (I) exper } & \multirow[b]{2}{*}{$(\mathrm{J})$ exper } & \multirow{2}{*}{$\begin{array}{l}\text { Mean } \\
(\mathrm{I}-\mathrm{J})\end{array}$} & \multirow{2}{*}{$\begin{array}{ll}\text { Difference } & \\
& \text { Std. Error }\end{array}$} & \multirow[b]{2}{*}{ Sig. } & \multicolumn{2}{|c|}{ 95\% Confidence Interval } \\
\hline & & & & & Lower Bound & Upper Bound \\
\hline \multirow[t]{3}{*}{1.00} & 2.00 & $-.9526^{*}$ & .01140 & .000 & -.9854 & -.9199 \\
\hline & 3.00 & $-1.1583^{*}$ & .01076 & .000 & -1.1892 & -1.1274 \\
\hline & 4.00 & $-1.4593^{*}$ & .01069 & .000 & -1.4900 & -1.4285 \\
\hline \multirow[t]{3}{*}{2.00} & 1.00 & $.9526^{*}$ & .01140 & .000 & .9199 & .9854 \\
\hline & 3.00 & $-.2057^{*}$ & .00632 & .000 & -.2239 & -.1875 \\
\hline & 4.00 & $-.5066^{*}$ & .00621 & .000 & -.5245 & -.4888 \\
\hline \multirow[t]{3}{*}{3.00} & 1.00 & $1.1583^{*}$ & .01076 & .000 & 1.1274 & 1.1892 \\
\hline & 2.00 & $.2057^{*}$ & .00632 & .000 & .1875 & .2239 \\
\hline & 4.00 & $-.3009^{*}$ & .00493 & .000 & -.3151 & -.2868 \\
\hline \multirow[t]{3}{*}{4.00} & 1.00 & $1.4593^{*}$ & .01069 & .000 & 1.4285 & 1.4900 \\
\hline & 2.00 & $.5066^{*}$ & .00621 & .000 & .4888 & .5245 \\
\hline & 3.00 & $.3009^{*}$ & .00493 & .000 & .2868 & .3151 \\
\hline *. The me & difference & nificant a & & & & \\
\hline
\end{tabular}




\section{Homogeneous Subsets}

Table 6. Performance

\begin{tabular}{|c|c|c|c|c|}
\hline \multicolumn{5}{|l|}{ Scheffe $\mathrm{e}^{\mathrm{a}, \mathrm{b}, \mathrm{c}}$} \\
\hline & & \multicolumn{3}{|l|}{ Subset } \\
\hline experience & $\mathrm{N}$ & 1 & 2 & 3 \\
\hline 1.00 & 5 & 2.9333 & & \\
\hline 2.00 & 19 & & 3.8860 & \\
\hline 3.00 & 40 & & & 4.0917 \\
\hline 4.00 & 45 & & & \\
\hline Sig. & & 1.000 & 1.000 & 1.000 \\
\hline \multirow{2}{*}{\multicolumn{5}{|c|}{$\begin{array}{l}\text { Means for groups in homogeneous subsets are displayed. } \\
\text { Based on observed means. }\end{array}$}} \\
\hline & \multicolumn{4}{|c|}{ Based on observed means. } \\
\hline \multicolumn{5}{|c|}{ The error term is Mean Square (Error) $=.001$. } \\
\hline \multirow{2}{*}{\multicolumn{5}{|c|}{$\begin{array}{l}\text { a. Uses Harmonic Mean Sample Size }=13.340 \text {. } \\
\text { b. The group sizes are unequal. The harmonic mean of the group sizes is used. Type I } \\
\text { error levels are not guaranteed. }\end{array}$}} \\
\hline & & & & \\
\hline \multicolumn{5}{|c|}{ c. Alpha $=0.05}$. \\
\hline
\end{tabular}

\section{Discussion}

Current study aimed at examining the role of AIS application in preserving financial performance of organizations during COVID19 pandemic through the moderating role of experience among accountants. Depending on quantitative approach, study utilized a questionnaire built on liker scale which was distributed on (109) individuals within Jordanian organizations. Results of study indicated that there was a positive impact of AIS applications on financial performance of organizations through covid19 lockdown that was attributed to experience of accountants on dealing with applications like AIS.

The current study demonstrated the ability of accounting information systems to "save" the financial performance of organizations by providing technology based on the accounting hierarchy in the basic processes and treatments of the system, given that accounting information systems represented formal systems of accounting information in any economic unit. This ability is somehow connected to experience of accountants who had the ability to deal with numerical data and process it through AIS application in a way that gives realistic indications of organizational financial performance. Study also shed the light on the role of accountants' experience in reaching the best outputs of AIS applications, the study has proven that accounting experience is important and has a clear impact on organizational financial performance. It is represented in the experience of accountants in computer skills and its applications related to the science of accounting, in addition to full awareness of all laws related to the work of accounting like taxes such as income and sales tax and commercial laws that would contribute to giving a clear overview of the financial performance of the organization as a whole, especially in special cases such as political instability, infectious diseases outbreak and natural disasters.

In addition, the study has shown that the closures that governments have been forced to have contributed to making accounting information systems the first destination for organizations in order to obtain their financial information easily, quickly and accurately by referring to the accurate inputs made by individuals, meaning that the correct entry leads to the correct outputs regardless of the existence of accounting books and actual dealings with working individuals and accountants in the organization. Hence, during the pandemic, organizations were able to keep their financial performance up-to-date by looking at the information they have, which greatly contributed to making governance and disclosure practices easy practices, the ease of which was represented in the availability of the necessary information represented by accuracy, control and Efficiency and classification.

These results are consistent with many previous studies such as studies Folger-Laronde et al (2020) and Khullar et al (2020) which have proven that computer information systems represented a non-manual means in order to quickly and accurately access the financial information of the organization and thus actual and daily knowledge of the financial performance of the organization in light of the pandemic and closures.

On the other hand, and looking at the results of the study, it was found that accounting information systems contributed during the pandemic period to enhancing the utilization of accounting information and its use in the service of financial performance by providing confidence in the information given its timing, accuracy, efficiency and creating a kind of classification. Positive is based on previously handled input. The study also indicated that accounting systems were among the facilities that emerged in order to evaluate the financial performance of the organization through oversight, as control represented a source of internal control and a great benefit for strategic planning and confidence in information. These results were consistent with Erdem (2020), 
Yarovaya et al (2021), and Rababah et al (2020) in addition to Ichsan et al (2021).

\section{Conclusion and Recommendations}

Generally speaking, AIS formed the strongest basis for ensuring the preservation of customer, vendor, and business information within organizations by setting up many policies and procedures that ensure workflow within different systems remotely, in order to achieve the characteristics of the required accounting information quality, as it can be used to obtain approvals for any material receipts as well as providing licenses and distinguishing between the duties required, as well as the relevant information can be used for each job of the business. This managed to preserve the financial performance of an organization during pandemic through focusing on the availability and quality of financial reports in a way that served if giving the actual and real picture of the organizational financial status.

Recommendations

Based on the aforementioned discussion and results, the present study recommends the following:

- The necessity of activating risk management strategies by organizations when facing crises and epidemics

- The need to adhere to social responsibility, especially in education and health organizations

- Allocating financial resources to confront crises and epidemics in order to be able to deal with them and avoid the losses.

\section{References}

Agung, M. (2015). Accounting information system and improvement on financial reporting. International Journal of Recent Advances in Multidisciplinary Research, 2(11), 950-957.

Aifuwa, H. O., Saidu, M., \& Aifuwa, S. A. (2020). Coronavirus pandemic outbreak and firms performance in Nigeria. Management and Human Resources Research, 5(8).

Al Hanini, E. (2015). Evaluating the Reliability of the Internal Control on the Computerized Accounting Information Systems: An Empirical Study on Banks Operating in Jordan. Research Journal of Finance and Accounting, 6(8).

Al-Hattami, H. M., Hashed, A. A., \& Kabra, J. D. (2021). Effect of AIS success on performance measures of SMEs: evidence from Yemen. International Journal of Business Information Systems, 36(1), 144-164. https://doi.org/10.1504/IJBIS.2021.112399

Ali, B. J., Omar, W. A. W., \& Bakar, R. (2016). Accounting Information System (AIS) and organizational performance: Moderating effect of organizational culture. International Journal of Economics, Commerce and Management, 4(4), 138-158.

Amahalu, N., Abiahu, M. F. C., \& Chinyere, O. (2017). Comparative analysis of computerized accounting system and manual accounting system of quoted Microfinance Banks (MFBs) in Nigeria. International Journal of Academic Research in Accounting, Finance and Management Sciences, 7(2), 30-43. https://doi.org/10.6007/IJARAFMS/v7-i2/2787

Arcega, C. K., Datinguinoo, E., Guerra, J., Guno, C., Mayuga, H. J., Villamena, E., \& Manongsong, J. L. (2015). Computerized vs. non-computerized accounting system of small and medium enterprises in Lipa City, Philippines: A comparative analysis. Asia Pacific journal of academic research in business administration, l(1), 48-55.

Basu, S., Phillips, R. S., Phillips, R., Peterson, L. E., \& Landon, B. E. (2020). Primary Care Practice Finances In The United States Amid The COVID-19 Pandemic: Study estimates the potential impact of COVID-19 on operating expenses and revenues of primary care practices. Health Affairs, 39(9), 1605-1614. https://doi.org/10.1377/hlthaff.2020.00794

Beg, K. (2018). Impact of Accounting Information system on the financial performance of Selected FMCG companies. Asian Journal of Applied Science and Technology, 2(3), 08-17.

Budiarto, D. S., Prabowo, M. A., Djajanto, L., Widodo, K. P., \& Herawan, T. (2018, May). Accounting information system (ais) alignment and non-financial performance in small firm: a contingency perspective. In International Conference on Computational Science and Its Applications (pp. 382-394). Springer, Cham. https://doi.org/10.1007/978-3-319-95165-2_27

Colenda, C. C., Applegate, W. B., Reifler, B. V., \& Blazer, D. G. (2020). COVID-19: Financial stress test for academic medical centers. Academic Medicine, 22(15). https://doi.org/10.1097/ACM.0000000000003418 
Considine, B., Parkes, A., Olesen, K., Blount, Y., \& Speer, D. (2012). Accounting Information Systems: understanding business processes. John Wiley \& Sons.

Daoud, H., \& Triki, M. (2013). Accounting information systems in an ERP environment and tunisian firm performance. International Journal of Digital Accounting Research, 13. https://doi.org/10.4192/1577-8517-v13_1

Erdem, O. (2020). Freedom and stock market performance during Covid-19 outbreak. Finance Research Letters. https://doi.org/10.1016/j.frl.2020.101671

Esmeray, A. (2016). The impact of accounting information systems (AIS) on firm performance: empirical evidence in Turkish small and medium sized enterprises. International Review of Management and Marketing, 6(2).

Folger-Laronde, Z., Pashang, S., Feor, L., \& ElAlfy, A. (2020). ESG ratings and financial performance of exchange-traded funds during the COVID-19 pandemic. Journal of Sustainable Finance \& Investment, 1-7. https://doi.org/10.1080/20430795.2020.1782814

Friede, G., Busch, T., \& Bassen, A. (2015). ESG and financial performance: aggregated evidence from more than 2000 empirical studies. Journal of Sustainable Finance \& Investment, 5(4), 210-233. https://doi.org/10.1080/20430795.2015.1118917

Galant, A., \& Cadez, S. (2017). Corporate social responsibility and financial performance relationship: a review of measurement approaches. Economic research-Ekonomska istraživanja, 30(1), 676-693. https://doi.org/10.1080/1331677X.2017.1313122

Ganyam, A. I., \& Ivungu, J. A. (2019). Effect of accounting information system on financial performance of firms: A review of literature. Journal of Business and Management, 21(5), 39-49.

Grande, E. U., Estébanez, R. P., \& Colomina, C. M. (2011). The impact of Accounting Information Systems (AIS) on performance measures: empirical evidence in Spanish SMEs. The international journal of digital accounting research, 11(1), 25-43. https://doi.org/10.4192/1577-8517-v11_2

Haleem, A., Kevin, L. L. T., \& Ahamed, S. T. (2019). An Evaluation of the Impact of AIS on the Accounting Practices implemented in the ERP Environment.

Hamdan, H. (2014). The Impact of Accounting Systems Development on the Performance Financial of Hotel Facilities (A Field Study on a Series of Five-Star Hotels in Jordan. MA Thesis, Middle East University Amman- Jordan.

He, H., \& Harris, L. (2020). The impact of Covid-19 pandemic on corporate social responsibility and marketing philosophy. Journal of Business Research, 116, 176-182. https://doi.org/10.1016/j.jbusres.2020.05.030

Ichsan, R. N., Suparmin, S., Yusuf, M., Ismal, R., \& Sitompul, S. (2021). Determinant of Sharia Bank's Financial Performance during the Covid-19 Pandemic. Budapest International Research and Critics Institute (BIRCI-Journal): Humanities and Social Sciences, 4(1), 298-309. https://doi.org/10.33258/birci.v4i1.1594

Kalbouneh, H. Y., Zreiqat, Q. M., Omar, M., \& Salameh, R. S. (2012). The Impact of Using Computerized Accounting Information Systems on Financial Performance - A Field Study on Jordanian Industrial Public Shareholding Companies. Journal of Islamic University, 19(2).

Khan, A. (2017). Impact of accounting information system on the organizational performance: a case study of Procter and Gamble. Star Research Journal, 5(12), 26-30.

Khullar, D., Bond, A. M., \& Schpero, W. L. (2020). COVID-19 and the financial health of US hospitals. Jama, 323(21), 2127-2128. https://doi.org/10.1001/jama.2020.6269

Moroșan-Dănilă, L. (2015). The stage of accounting computerization in Romania. Стан та Перспективи Розвитку Обліково-Аналітичного Забезпечення Управління Підприємницькою Діяльністю в Умовах Євроінтеграційних Процесів, Ukraine, 185-187.

Murungi, S., \& Kayigamba, C. (2015). The impact of computerized accounting system on financial reporting in the ministry of local government of Rwanda. Journal of Emerging Trends in Economics and Management Sciences, 6(4), 261-265.

Nazar, M. C. A. (2020). Factors Affecting the Effectiveness of Accounting Information Systems in Public Listed Companies in Sri Lanka. Int. J. Adv. Multidiscip. Res, 7(9), 1-6.

Nyang'au, R. N., Okibo, B. W., \& Nyanga'u, A. (2015). Constraints affecting adoption of computerized 
accounting systems in Nyeri county, Kenya. International Journal of Economics, Commerce and Management, 3(5), 15-36.

Oldekop, J. A., Horner, R., Hulme, D., Adhikari, R., Agarwal, B., Alford, M., ... Zhang, Y. F. (2020). COVID-19 and the case for global development. World Development, 134, 105044. https://doi.org/10.1016/j.worlddev.2020.105044

Ozili, P. K. (2020). Accounting and financial reporting during a pandemic. Available at SSRN 3613459. https://doi.org/10.2139/ssrn.3613459

Parr, S., Wolshon, B., Renne, J., Murray-Tuite, P., \& Kim, K. (2020). Traffic impacts of the COVID-19 pandemic: Statewide analysis of social separation and activity restriction. Natural hazards review, 21(3), 04020025. https://doi.org/10.1061/(ASCE)NH.1527-6996.0000409

Pirayesh, R., Forouzandeh, M., \& Louie, S. I. (2018). Examining the effect of computerized accounting information system on managers' decision making process. Revista Publicando, 5(14), 68-82.

Post, C., \& Byron, K. (2015). Women on boards and firm financial performance: A meta-analysis. Academy of management Journal, 58(5), 1546-1571. https://doi.org/10.5465/amj.2013.0319

Prasad, A., \& Green, P. (2015). Organizational competencies and dynamic accounting information system capability: impact on AIS processes and firm performance. Journal of Information Systems, 29(3), 123-149. https://doi.org/10.2308/isys-51127

Rababah, A., Al-Haddad, L., Sial, M. S., Chunmei, Z., \& Cherian, J. (2020). Analyzing the effects of COVID-19 pandemic on the financial performance of Chinese listed companies. Journal of Public Affairs, 20(4), e2440. https://doi.org/10.1002/pa.2440

Razumovskaia, E., Yuzvovich, L., Kniazeva, E., Klimenko, M., \& Shelyakin, V. (2020). The Effectiveness of Russian Government Policy to Support SMEs in the COVID-19 Pandemic. Journal of Open Innovation: Technology, Market, and Complexity, 6(4), 160. https://doi.org/10.3390/joitmc6040160

Soudani, S. N. (2012). The usefulness of an accounting information system for effective organizational performance. International Journal of Economics and Finance, 4(5), 136-145. https://doi.org/10.5539/ijef.v4n5p136

Talwar, M., Talwar, S., Kaur, P., Tripathy, N., \& Dhir, A. (2021). Has financial attitude impacted the trading activity of retail investors during the COVID-19 pandemic? Journal of Retailing and Consumer Services, 58, 102341. https://doi.org/10.1016/j.jretconser.2020.102341

Urquia, G. E., Pérez Estébanez, R., \& Munoz Colomina, C. (2011). The impact of Accounting Information Systems (AIS) on performance measures: empirical evidence in Spanish SMEs.

Ware, E. O. (2015). Computerised accounting system an effective means of keeping accounting records in Ghanaian banks: A case study of the Ga Rural Bank. International Journal of Research, 111.

Widiatmika, P. H., \& Darma, G. S. (2018). Good Corporate Governance, Job Motivation, Organization Culture Which Impact Company Financial Performance. Jurnal Manajemen Bisnis, 15(3), 82-99.

World Bank. (2020). Government Financial Reporting in Times of the COVID-19 Pandemic.

Yan, W., \& Sloan, M. F. (2016). The impact of employee compensation and financial performance on nonprofit organization donations. The American Review of Public Administration, 46(2), 243-258. https://doi.org/10.1177/0275074014554000

Yarovaya, L., Mirza, N., Abaidi, J., \& Hasnaoui, A. (2021). Human capital efficiency and equity funds' performance during the COVID-19 pandemic. International Review of Economics \& Finance, 71, 584-591. https://doi.org/10.1016/j.iref.2020.09.017

\section{Copyrights}

Copyright for this article is retained by the author(s), with first publication rights granted to the journal.

This is an open-access article distributed under the terms and conditions of the Creative Commons Attribution license (http://creativecommons.org/licenses/by/4.0/). 